\title{
The Interactions of Rhizodeposits with Plant Growth-Promoting Rhizobacteria in the Rhizosphere: A Review
}

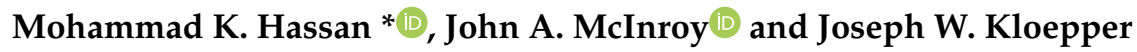 \\ Department of Entomology and Plant Pathology, Auburn University, CASIC Building, Auburn, AL 36849, USA \\ * Correspondence: mkh0025@auburn.edu; Tel.: +1-(334)-498-9264
}

Received: 2 June 2019; Accepted: 2 July 2019; Published: 4 July 2019

check for updates

\begin{abstract}
Rhizodeposits, root exudates, and root border cells are vital components of the rhizosphere that significantly affect root colonization capacity and multiplication of rhizosphere microbes, as well as secretion of organic bioactive compounds. The rhizosphere is an ecological niche, in which beneficial bacteria compete with other microbiota for organic carbon compounds and interact with plants through root colonization activity to the soil. Some of these root-colonizing beneficial rhizobacteria also colonize endophytically and multiply inside plant roots. In the rhizosphere, these components contribute to complex physiological processes, including cell growth, cell differentiation, and suppression of plant pathogenic microbes. Understanding how rhizodeposits, root exudates, and root border cells interact in the rhizosphere in the presence of rhizobacterial populations is necessary to decipher their synergistic role for the improvement of plant health. This review highlights the diversity of plant growth-promoting rhizobacteria (PGPR) genera, their functions, and the interactions with rhizodeposits in the rhizosphere.
\end{abstract}

Keywords: rhizodeposits; root exudates; root border cells; PGPR; rhizosphere; organic bioactive compounds; root colonization; plant health; biological control

\section{Introduction}

Hiltner first coined the term "rhizosphere" as the area of microbial activity around roots [1]. Pinton et al. [2] defined the rhizosphere as the volume of soil affected by exudates from plant root tissues and colonized by rhizobacteria. It has been estimated that bacterial populations in the rhizosphere, are 10-100 times higher than in bulk soil [3,4]. In the rhizosphere, rhizobacterial interactions with plant roots can be positive, negative, or neutral. Positive interactions can result in enhanced plant growth and suppression of plant pathogens [5]. Lynch [6] proposed three different zones of the rhizosphere: the endorhizosphere (the endodermis and cortical layers inside the root), the rhizoplane (the root surface with mucilaginous polysaccharide layer), and the ectorhizosphere (soil particles past the root surface that are impacted by root exudates). Currently, the zone that Lynch termed the "endorhizosphere" is commonly referred to as "internal root colonization" because it is a physical location inside the plant rather than a "sphere" outside of the root. Compared to bulk soil, the endorhizosphere is abundant in various nutrients due to an aggregation of root exudates [7], including amino acids, sugars, organic acids, vitamins, and enzymes [8]. Root exudates release ions, oxygen, and water, but most importantly include carbon-containing compounds [9]. Some root exudates function as repellents against pathogens while others function as attractants that aggregate beneficial microbes [10] based on the physiological status, species of plants, and microorganisms [11].

In the rhizosphere, various interactions occur between rhizobacteria and plant. For example, interactions of signal molecules between plant roots and rhizobacteria are equally important and occur 
in the rhizosphere [12,13], and these interactions that influence plant growth and crop yields [14] can be root-root, root-insect, and root-microbe interactions [15]. The role of the rhizosphere is pivotal for plant growth-promotion, nutrition, and crop quality [16] because of the importance of plant-microbe interactions in the rhizosphere carbon sequestration, nutrient cycling, and ecosystem functioning [17]. In addition, the rhizosphere is where plant roots communicate with beneficial rhizobacteria for energy and nutrition. Plant growth-promoting rhizobacteria (PGPR) may affect plant growth, development, and disease suppression by one or more direct or indirect mechanisms. Bacterial genera such as Bacillus and Pseudomonas have been extensively studied and utilized as biocontrol agents, biofertilizers, and also have been shown to trigger induced systemic resistance (ISR) [18-24]. In this review, we discuss the importance, functions, and effects of root-derived organic molecules secreted in the rhizosphere and their interactions with plant growth-promoting rhizobacteria (PGPR) for enhancing plant growth and biological control of plant pathogens.

\section{PGPR Diversity in the Rhizosphere}

The plant rhizosphere contains diverse rhizobacterial species with the potential to enhance plant growth and biological control activity. PGPR genera present in the rhizosphere include Agrobacterium, Arthrobacter, Azotobacter, Azospirillum, Bacillus, Burkholderia, Caulobacter, Chromobacterium, Erwinia, Flavobacterium, Micrococcous, Pseudomonas, Serratia, and Cellulomonas Flavigena [8,25-28]. Nitrogen-fixing endophytic rhizobacterial genera such as Allorhizobium, Azorhizobium, Bradyrhizobium, Mesorhizobium, and Rhizobium of the family Rhizobiaceae internally colonize legume plants roots to form nodules and increase plant growth directly or indirectly [29-31]. Other genera of PGPR such as Pantoea, Methylobacterium, Exiguobacterium, Paenibacillus, and Azoarcus also colonize roots and exhibit many beneficial effects on plants [32]. Two novel proteobacterial strains (WRB 10 Alcaligenes sp. and WRB 4 Providencia sp.) enhanced root colonization and growth-promotion of wheat [33]. Actinomycetes are another group of rhizobacteria that stimulate plant growth and suppress plant pathogens through root colonization. Some strains of Actinomycete genera Streptomyces, Streptosporangium, Thermobifida, and Micromonospora have been reported to exhibit biological control activity against root fungal pathogens [34]. For example, Lee and Hwang [35] reported that some actinomycete isolates, including species in the genera Streptomyces, Micromonospora, Dactylosporangium, Actinomadura, Streptosporangium, and Nocardioform exhibited strong antifungal activity against the fungal plant pathogens Alternaria mali, Colletotrichum gloeosporioides, Fusarium oxysporum f. sp. cucumerinum, and Rhizoctonia solani. The root-derived nutrients attract PGPR in the rhizosphere for root colonization and repel plant pathogens to avoid root damage. In return, the plant receives various nutrients through PGPR root colonization and multiplication inside and outside of plant roots. Hence, PGPR and roots develop interdependent relationships.

\section{Root Colonization Capacity of PGPR}

The concept of root colonization in the broadest sense refers to the multiplication of rhizobacterial populations ectophytically in the rhizosphere, on the root surface, and endophytically inside roots [36]. Root colonization by PGPR is considered a prerequisite for plant growth-promotion. Rhizobacteria disseminate from a source of inoculum, such as seed treatments, to the actively growing root region and multiply or grow in the rhizosphere, a process referred to as root colonization [36]. The dispersal of rhizobacteria from the inoculation site to the growing region of roots occurs by both active and passive movement of bacteria [37]. One root colonization model proposed by Newman and Watson predicts that an abundance of rhizobacteria occurs near the root tip region of the growing plant [38]. The migration of rhizobacteria from the seed (point of inoculation) to the growing region of roots is governed by both active and passive movement mechanisms [37]. Howie et al. [39] suggested that root colonization by Pseudomonas fluorescens strain 2-79 takes place by passive transport on the root tip. Bacterial lipopolysaccharides (LPS), especially the O-antigen, can play important roles in root colonization [40], with some PGPR strain-dependent. For example, the O-antigenic side chain 
of Pseudomonas fluorescens WCS374 did not aid in root adhesion of potato [41]. Studies have shown that synthesis of $B_{1}$ vitamin and secretion of nicotinamide adenine dinucleotide hydrate (NADH) dehydrogenases contribute to root colonization by PGPR [42]. Another study revealed that type IV pili of bacteria were involved in plant root colonization by endophytic bacteria Azospirillum species [43]. In certain bacteria, successful root colonization is associated with secretion of a site-specific recombinase gene [44], and transfer of this gene from wild type Pseudomonas spp. to poor colonizer P. fluorescens strain WCS307 increased colonization of root tips [45]. Another study conducted by Xu et al. [46] reported that wall teichoic acid (WTA) in B. velezensis SQR9 is crucial for root colonization and biofilm formation.

\section{The Significance of Nutrient Uptake by PGPR}

Plants uptake nutrients through roots as an essential part of their growth and survival. Active root colonization by bacteria in the rhizosphere is crucial for healthy plant growth and is affected by interactions among the soil, plant, and indigenous rhizobacteria. Successful plant growth-promotion suggests that rhizobacteria colonized and communicated with plant roots properly in the rhizosphere. During root colonization, some PGPR enhance the availability of nutrients in the rhizosphere, thereby enabling increased plant growth [47]. The process by which this enhancement occurs includes solubilization of unavailable forms of nutrients (phosphate and nitrogen) and production of siderophores, which chelate and release iron for the plant in iron-limited conditions [48-50]. In addition, various rhizobacteria produce one or more type of phytohormones in the rhizosphere, and various phytohormone-producing genes can be activated by organic compounds that are abundant in the root cap and the elongation zone [51]. For example, Lakshmanan et al. [52] reported that Arabidopsis thaliana roots treated with B. subtilis strain FB17 strain expressed multiple genes including auxin-regulated genes involved in metabolism, stress response, and plant defense during root colonization process.

\section{Root Exudation}

The quantity and type of root exudates produced from growing roots vary with plant species, age, and stress-associated factors [9]. Root exudates are the central source of nutrients in the rhizosphere, creating a niche for growth of rhizosphere microorganisms [53,54]. Bolton et al. [55] defined root exudates as "low molecular weight organic compounds which leak from intact root cells". Root secretion and release of organic compounds are also referred to as root exudation, and it can be divided into active root excretion with unknown functions and secretion of compounds from roots with known functions such as lubrication and defense of plant roots (Figure 1) $[9,56]$. Root exudates include low and high molecular weight organic compounds (Figure 1) [15]. Low molecular weight organic compounds such as amino acids, organic acids, sugars, and phenolics are highly diverse compounds that are released from intact root cells [55]. High molecular weight organic compounds such as mucilage (polysaccharides) and proteins secreted by root cap cells and epidermal cells are involved in the enhancement of root-soil interactions and facilitate root movement through the soil [57]. Plant root exudates play an essential role in resource competition and chemical interference [15]. Tsuno et al. [58] reported that soybean roots secrete large amounts of soyasaponins (a new type of root exudate) during the vegetative emergence (VE) stage of growth. Liu et al. [59] found that soybean root exudates trigger early symbiotic associations between Bacillus diazoefficiens and soybean. Root exudates serve as a messenger between roots and rhizobacteria in the rhizosphere [60]. They protect roots from desiccation, root-soil interactions, lubrication of the root tips, and help with storage of ions [61,62]. Hence, root exudates are essential for interactions between microorganisms leading to plant growth-promotion and induced defenses against plant pathogens. The classification and functions of root exudates are shown in Table 1. 


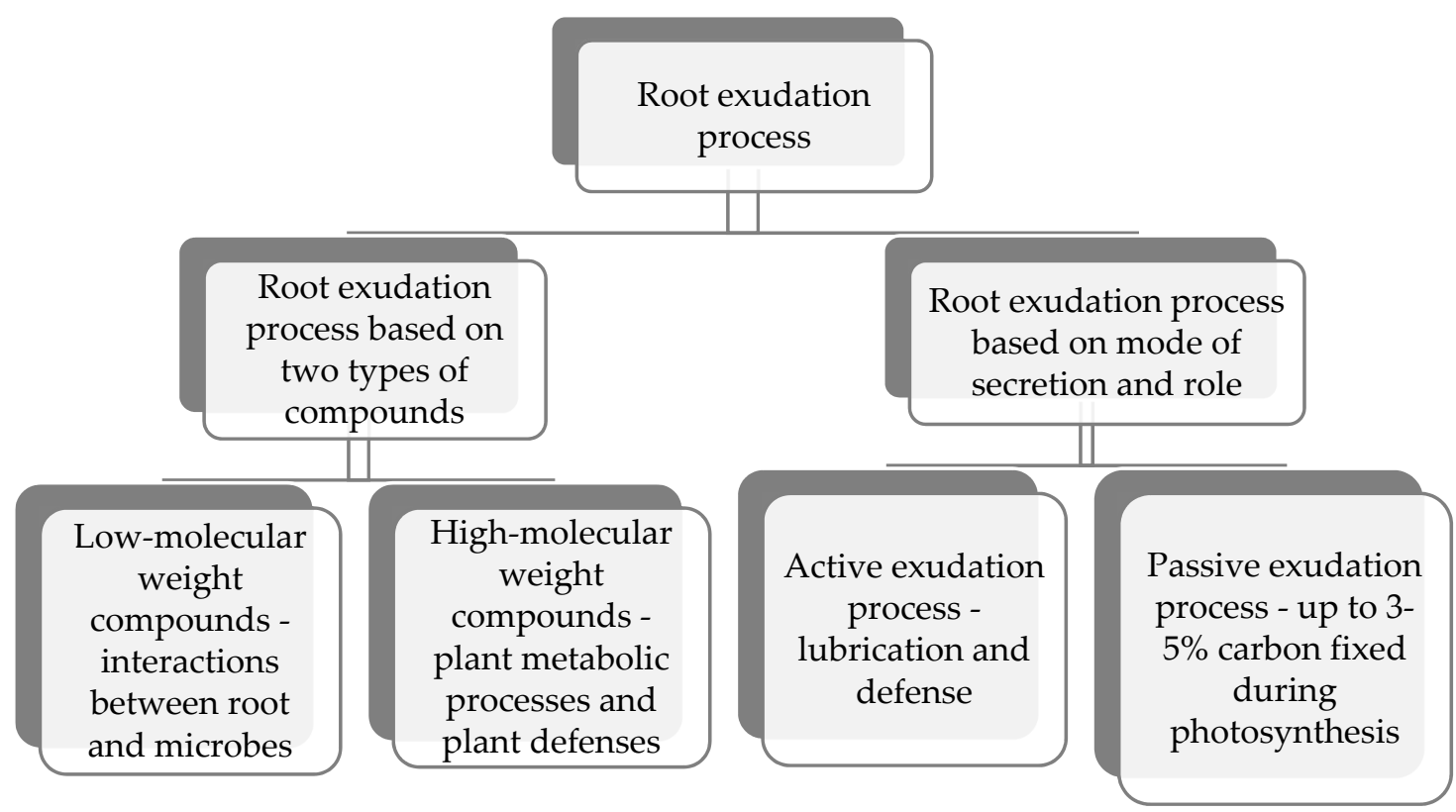

Figure 1. Types of root exudation processes that provide nutrients for plant growth-promoting rhizobacteria (PGPR) root colonization and growth based on classes of compounds, secretions, and their functions in the rhizosphere $[15,55-57,63,68]$.

Table 1. Organic bioactive compounds secreted as rhizodeposits, root exudates, and root border cells in the rhizosphere that repel plant pathogens and attract beneficial rhizobacteria [9,63-67].

\begin{tabular}{cc}
\hline Secreted Compounds & $\begin{array}{c}\text { Secreted Materials Released from Plant Roots as a Nutrient } \\
\text { Rhizodeposits }\end{array}$ \\
\hline $\begin{array}{c}\text { Water-soluble exudates, secretions of } \\
\text { insoluble materials, lysates, dead fine roots, } \\
\text { gases }\left(\mathrm{CO}_{2} \text { and ethylene), inorganic ions }\right.\end{array}$ \\
Root exudates & $\begin{array}{c}\text { Sugars, amino compounds, organic acids, } \\
\text { fatty acids, sterols, growth factors, nucleotides, } \\
\text { flavanones, and enzymes }\end{array}$ \\
\hline Root border cells & $\begin{array}{c}\text { Antimicrobial proteins, phytoalexins, antibiotics, } \\
\text { arabinogalactan proteins, extracellular enzymes, and pectins }\end{array}$ \\
\hline
\end{tabular}

\section{Rhizodeposition}

The release or loss of carbon compounds from plant roots into the surrounding soil environment is referred to as rhizodeposition [69]. Rhizodeposition drives the interactions between plant, soil, and microbial populations [70,71]. Rhizodeposits include root cap cells, lysates, secretions, root exudates, mucilage, and mucigel. Many biotic and abiotic factors affect the rhizodeposition process in growing roots. These include biotic factors such as plant species, photosynthesis, the supply of carbon from shoot to root, root architecture, mycorrhiza, and nodulation [72]. Abiotic factors that influence rhizodeposition include temperature, moisture, humidity, rooting depth, soil texture, and atmospheric nitrogen deposition [72]. Rhizodeposits released near the apical root region or root cap and secreted polysaccharide mucilages make up $2-12 \%$ of total rhizodeposition $[68,73]$. Organic compounds released by plant roots by rhizodeposition include sugars, amino acids, organic acids, enzymes, fatty acids, growth factors, and vitamins [74,75]. This wide variety of substances originates from sloughed-off root cap cells, mucilages, volatiles, soluble lysates, and exudates that are secreted from damaged and intact root cells $[7,69]$. Root exudation is a process of the rhizodeposition activity, which is a crucial source of soil organic carbon compounds released by plant roots $[63,76]$. Rhizodeposition controls multiple ecological soil functions including availability and mobilization of nutrients [76], the formation of soil aggregates [68], carbon sequestration [77], and structuring of microbial communities [77]. Organic compounds such as sugars, amino acids, and carboxylic acids exuded by roots constitute up to $10 \%$ of 
rhizodeposition [72]. Kuzyakov et al. [64] reported that rhizodeposits supply energy to soil microbes for solubilization of organic nitrogen and other nutrients in soil organic matter. White et al. [78] reported that isoflavonoids are vital rhizodeposits that help in plant defense and also facilitate symbiotic events with Rhizobia in soybean.

\section{Root Border Cells}

Hawes et al. [79] first proposed the term "root border cells" for root cells that are naturally sloughed-off from root tips of healthy plants [80,81]. Separation of these root border cells varies depending on plant species, genotype, and environmental conditions $[82,83]$. The role of root border cells in the rhizosphere has been extensively studied, and multiple functions have been reported. Pectin-degrading enzymes, such as methylesterases and polygalacturonases, are important for the separation of root border cells from the root tip $[84,85]$. The cell walls of root border cells contain pectin polysaccharides that are also available in the secreted mucilage of the root cap $[65,86]$. Although root border cells are separated from the root cap region, they remain viable based on the availability of the nutrients, and the percentage of viable cells can be as high as 90 [79]. Root border cells are reported to affect several important rhizosphere processes. Root border cells have multiple effects on plant pathogenic bacteria and fungi, such as chemoattraction, repulsion, and suppression of plant pathogenic infection (Figure 2) $[87,88]$. In addition to, root border cells can stimulate plant growth-promotion elicited by root-colonizing PGPR [88]. Canellas and Olivares [89] reported that humic acid enhanced the production of border cells and colonization of maize root tips by the beneficial nitrogen-fixing bacterium Herbaspirillum seropedicae. In addition, root border cells secrete antimicrobial compounds, such as phenolics and arabinogalactan proteins, that suppress pathogens in the rhizosphere $[66,90]$. For example, the secretion of arabinogalactan proteins inhibited zoospore germination of Aphanomyces euteiches, which causes root-rot of legumes [65]. The secretion of root border cells in the root tip region are more pressing because most of the plant pathogens entry point is root tip. That is why root tip regions are crucial for attracting PGPR and repelling plant pathogens.

\section{Rhizodeposition, Exudates, and Border Cells in the Growing Plant Root}

Rhizodeposition and root exudates have been largely discussed in the literature of root colonization by PGPR rather than in relation to root border cells. The contribution of root border cells to plant root growth is immense for plant growth-promotion and development (Figure 2). Rhizodeposition takes place in different root zones (mature, elongation, and division zones), with the release of organic compounds by actively growing plant roots [63,91]. Rhizodeposits can occur in root cap cells, root tissues, mucilage, and root exudates [63,92]. Exudation occurs in the elongation zone, where root exudates and bacterial abundance is high [93]. Root exudates are a significant part of the rhizodeposition processes [63] and are released near the apical meristem of tap and lateral root [75]. Root exudates can be active, functioning in defense and lubrication, and passive based on their function and mode of secretion from the roots [15,72]. Border cells are released at the root cap and in the cell division zone. Root exudates, nutrient availability, and bacterial growth are high in detached root cap cells or root border cells [91,93]. Border cells secrete antimicrobial proteins, phytoalexins, and arabinogalactan proteins $[86,94]$. Driouich et al. [81] concluded that border cells can influence root-rhizosphere interactions at the root tip. Root exudates and border cells secrete different organic compounds and proteins, that function to attract beneficial microbes and repel harmful microbes [79]. Dennis et al. [74] reported that border cells themselves are part of rhizodeposits like exudates that are released from the root cap cells. Thus, rhizodeposits, root exudates, and root border cells shape microbial communities in the rhizosphere, thereby allowing plants to uptake a wider variety of nutrients for growth [95]. In addition to supplying nutrients for PGPR, these three components play a crucial role against multiple plant pathogens, such as plant pathogenic bacteria, fungi, nematodes, and viruses. The various organic compounds identified as rhizodeposits, exudates, and border cells that are released from plant root regions in the rhizosphere are shown in Table 1. 

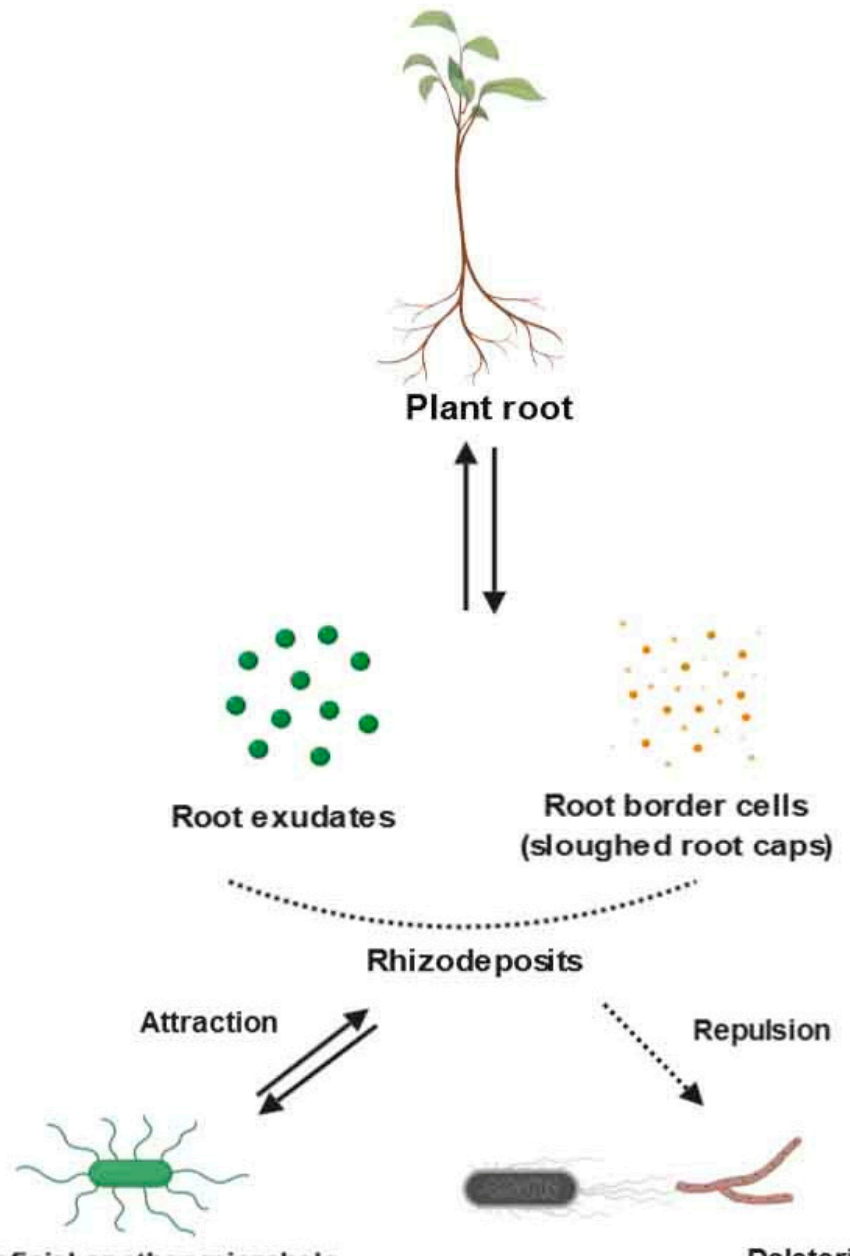

Beneficial or other microbe's (Rhizobacteria or root colonizing pathogens)
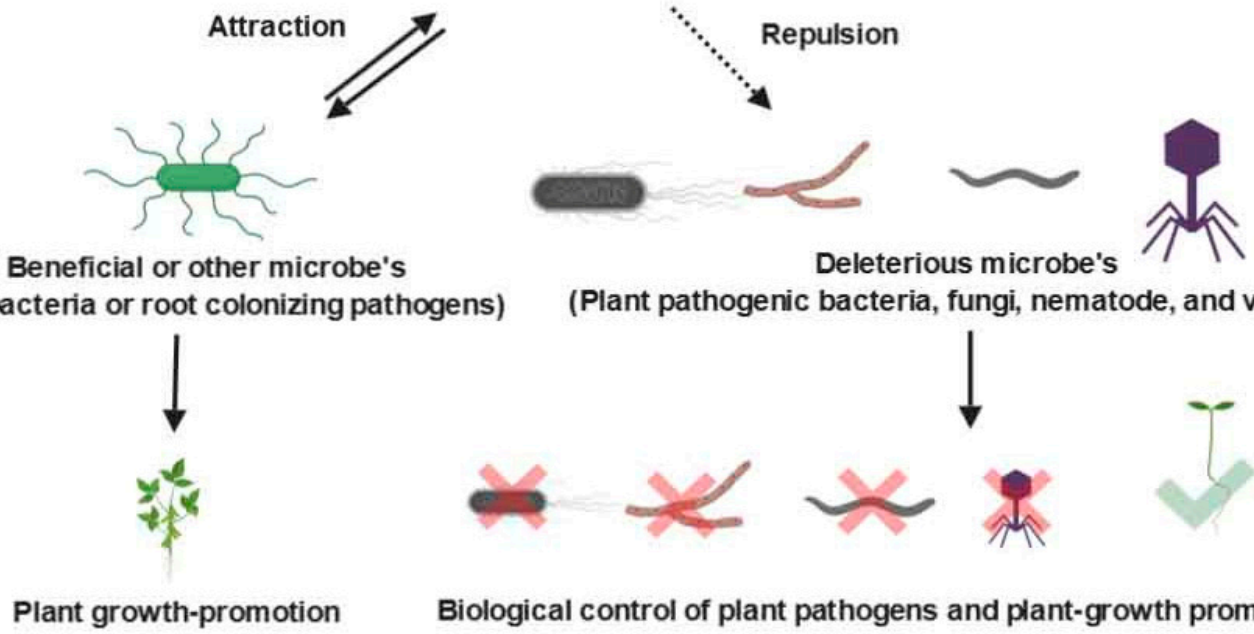

(Plant pathogenic bacteria, fungi, nematode, and viruses)
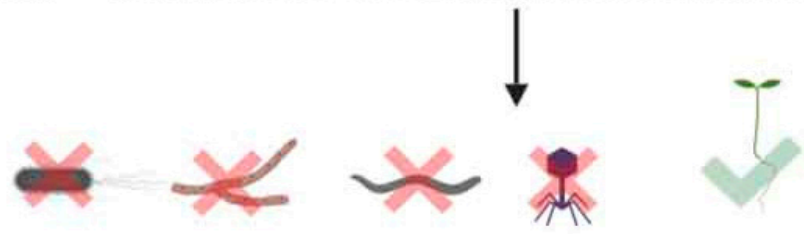

Figure 2. Interactions between bioactive organic compounds secreted by plant roots and beneficial or deleterious microbes resulting in attraction or repulsion (created with Biorender.com).

\section{Communication between PGPR, Rhizodeposits, and Roots in the Rhizosphere}

Communication between microbes and plant roots is interdependent, and it can be root-root or root-microbe in which both exchange nutrients for survival. Various types of relationships such as associative, symbiotic, neutral, or parasitic, can be developed based on the nutrient abundance in soil [96]. Secretion of organic compounds from plant lateral roots helps to aggregate microbes in the rhizosphere (Figure 3). Root exudates are phytochemicals released by plant roots that actively regulate symbiotic interactions with rhizobacteria in active soil zones of the rhizosphere $[97,98]$. Plant-microbe interactions, governed by root exudates via the chemotactic response of the microbes toward root-secreted organic compounds, play an important role in root colonization and biological control (antifungal, antibacterial, and antiviral) activities [99-101]. For example, the endophytic bacteria Corynebacterium flavescens and B. pumilus showed a fivefold increase of chemotaxis activity over other bacterial strains in the rice rhizosphere in the presence of amino acids and carbohydrate 
root exudates [102]. The release of root border cells also influences plant-microbe interactions. Hawes et al. [79] reported that root border cells stimulate growth and chemoattraction of bacteria and fungi. In plant-microbe interactions, antimicrobial compounds from the root exudates and border cells in the rhizosphere enhance plant growth and suppress various bacterial and fungal pathogens. For example, a complex mixture of extracellular proteins released into the rhizosphere from the root cap of pea plants as root border cells inhibited the soil-borne pea pathogen Nectria haematococca [66]. Bais et al. [103] suggested that the secretion of antimicrobial metabolites by root exudation inhibited multiple bacterial pathogens, including Erwinia carotovora, E. amylovora, Xanthomonas campestris pv. vesicatoria, and Pseudomonas fluorescens. In addition to root border cells, root exudates in the rhizosphere region are also affected by the biotic and abiotic factors. For example, the root exudation process can change the biotic and abiotic factors of the root zone [104]. Additionally, different PGPR genera may respond differently to soil rhizosphere nutrients due to the secretion of multiple compounds, because some PGPR-secreted compounds suppress plant pathogens, while other secreted compounds enhance plant growth (Figure 2). In addition to suppression of plant pathogens, PGPR also competes with other microbiota for acquiring nutrients in the rhizosphere. Hence, root border cells and exudates are essential for plant growth and inhibition of a range of soil-borne plant pathogens (Figure 2).

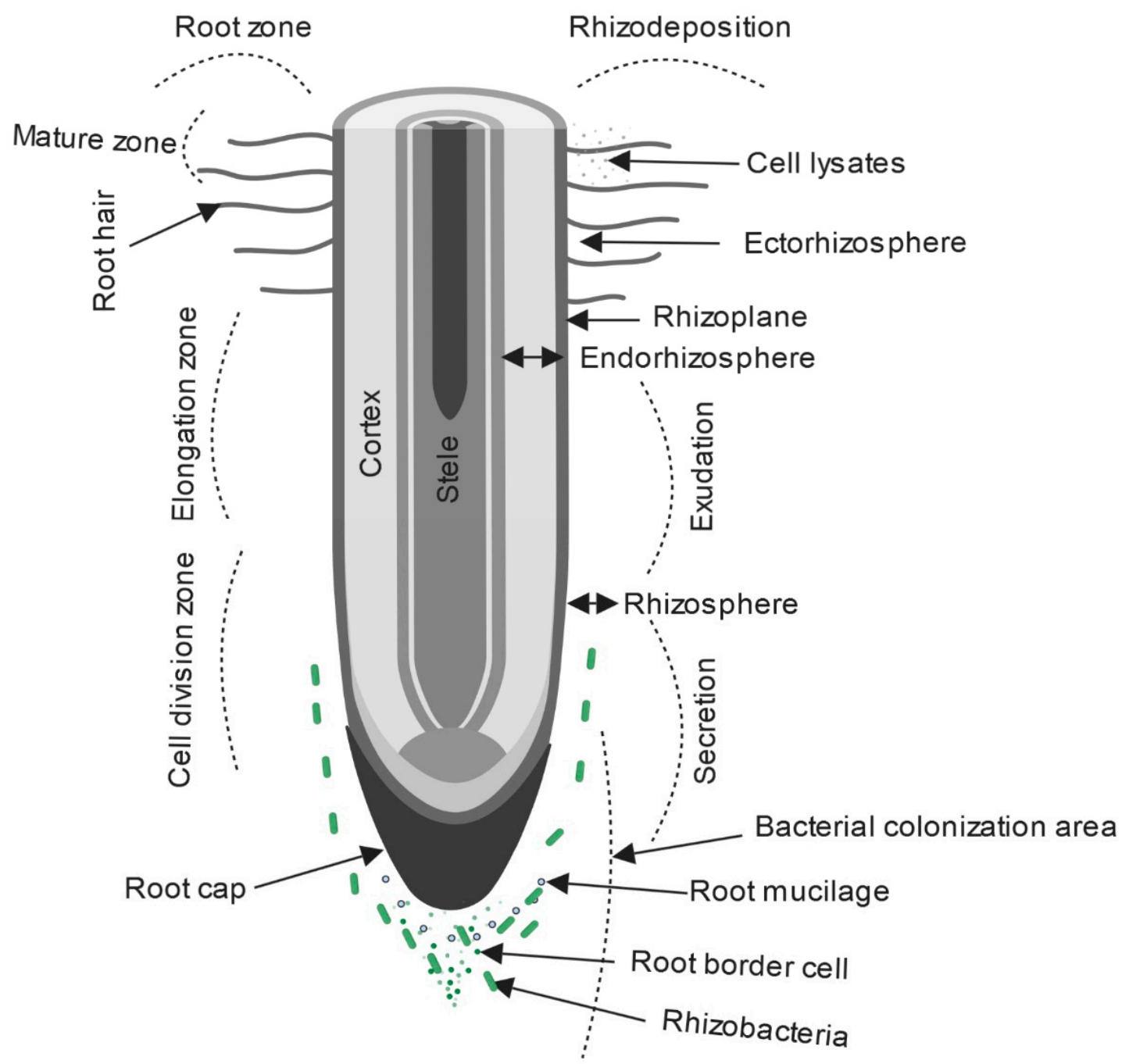

Figure 3. Types of different root zones in the rhizosphere where rhizodeposition, root exudates, and root border cells provide nutrients for PGPR growth and root colonization (created with Biorender.com) [57, $105,106]$. 


\section{Conclusions}

The secretion of bioactive phytochemicals in the rhizosphere as a carbon and energy source for plant roots attracts various beneficial bacteria and helps enhance root colonizing capacity of PGPR resulting in a mutually beneficial relationship between rhizobacteria and plant roots. PGPR influence plant growth-promotion through the utilization and colonization of root-secreted organic compounds. Furthermore, the synergistic beneficial effects of multiple PGPR genera act on different parts of plants that secrete secondary metabolites in the rhizosphere. The rhizosphere is an ecological hub in the soil, where root-secreted organic compounds are abundant and where the potential of PGPR strains to enhance plant growth is increased. Rhizodeposits, root exudates, and root border cells are driving forces for plant growth-promotion and biological control activities in the rhizosphere. Our knowledge of these root-secreted organic compounds and their functions are limited due to the complexities of conducting real-time rhizosphere studies in field and greenhouse studies. Molecular techniques in rhizosphere studies have broadened and revealed interactions between root and microbes. Developing new state of the art technologies to study rhizosphere ecology will aid in further understanding the role and utilization of the wide variety of bioactive phytochemicals produced by PGPR and affecting root colonization capacity, plant growth-promotion, and biological control.

Author Contributions: All authors contributed to this review.

Funding: This research received no external funding.

Acknowledgments: The authors are grateful to the J.W.K. lab in the Department of Entomology and Plant Pathology at Auburn University, Auburn, AL 36849, USA.

Conflicts of Interest: The authors declare no conflict of interest.

\section{References}

1. Hiltner, L. Uber nevere Erfahrungen und Probleme auf dem Gebiet der Boden Bakteriologie und unter besonderer Beurchsichtigung der Grundungung und Broche. Arbeit. Deut. Landw. Ges. Berlin 1904, 98, 59-78.

2. Pinton, R.; Varanini, Z.; Nannipieri, P. The Rhizosphere: Biochemistry and Organic Substances at the Soil-Plant Interface; CRC Press: Boca Raton, FL, USA, 2007.

3. Weller, D.M.; Thomashow, L.S. Current challenges in introducing beneficial microorganisms into the rhizosphere. In Molecular Ecology of Rhizosphere Microorganisms: Biotechnology and the Release of GMOs; VCH: Weinheim, Germany, 1994; pp. 1-18.

4. Berendsen, R.L.; Pieterse, C.M.; Bakker, P.A. The rhizosphere microbiome and plant health. Trends Plant Sci. 2012, 17, 478-486. [CrossRef] [PubMed]

5. Morgan, J.A.W.; Bending, G.D.; White, P.J. Biological costs and benefits to plant-microbe interactions in the rhizosphere. J. Exp. Bot. 2005, 56, 1729-1739. [CrossRef] [PubMed]

6. Lynch, J.; Whipps, J. Substrate flow in the rhizosphere. In The Rhizosphere and Plant Growth; Springer: Dordrecht, The Netherlands, 1991; pp. 15-24.

7. Dakora, F.D.; Phillips, D.A. Root exudates as mediators of mineral acquisition in low-nutrient environments. In Food Security in Nutrient-Stressed Environments: Exploiting Plants' Genetic Capabilities; Springer: Dordrecht, The Netherlands, 2002; pp. 201-213.

8. Gray, E.; Smith, D. Intracellular and extracellular PGPR: Commonalities and distinctions in the plant-bacterium signaling processes. Soil Biol. Biochem. 2005, 37, 395-412. [CrossRef]

9. Uren, N.C. Types, amounts, and possible functions of compounds released into the rhizosphere by soil-grown plants. In The Rhizosphere; CRC Press: Boca Raton, FL, USA, 2000; pp. 35-56.

10. Ahemad, M.; Kibret, M. Mechanisms and applications of plant growth promoting rhizobacteria: Current perspective. J. King Saud Univ. Sci. 2014, 26, 1-20. [CrossRef]

11. Kang, B.G.; Kim, W.T.; Yun, H.S.; Chang, S.C. Use of plant growth-promoting rhizobacteria to control stress responses of plant roots. Plant Biotechnol. Rep. 2010, 4, 179-183. [CrossRef]

12. Weller, D. Colonization of wheat roots by a fluorescent pseudomonad suppressive to take-all. Phytopathology 1983, 73, 1548-1553. [CrossRef] 
13. Werner, D. Organic signals between plants and microorganisms. In The Rhizosphere: Biochemistry and Organic Substances at the Soil-Plant Interface; Marcel Dekker: New York, NY, USA, 2000; pp. 197-222.

14. Shaikh, S.; Wani, S.; Sayyed, R. Impact of Interactions between Rhizosphere and Rhizobacteria: A Review. J. Bacteriol. Mycol. 2018, 5, 1058.

15. Bais, H.P.; Weir, T.L.; Perry, L.G.; Gilroy, S.; Vivanco, J.M. The role of root exudates in rhizosphere interactions with plants and other organisms. Annu. Rev. Plant Biol. 2006, 57, 233-266. [CrossRef]

16. Berg, G.; Smalla, K. Plant species and soil type cooperatively shape the structure and function of microbial communities in the rhizosphere. FEMS Microbiol. Ecol. 2009, 68, 1-13. [CrossRef]

17. Singh, B.K.; Millard, P.; Whiteley, A.S.; Murrell, J.C. Unravelling rhizosphere-microbial interactions: Opportunities and limitations. Trends Microbiol. 2004, 12, 386-393. [CrossRef] [PubMed]

18. Kloepper, J.W.; Ryu, C.-M.; Zhang, S. Induced systemic resistance and promotion of plant growth by Bacillus spp. Phytopathology 2004, 94, 1259-1266. [CrossRef] [PubMed]

19. Van Wees, S.C.; Van Der Ent, S.; Pieterse, C.M. Plant immune responses triggered by beneficial microbes. Curr. Opin. Plant Biol. 2008, 11, 443-448. [CrossRef] [PubMed]

20. Ahmad, F.; Ahmad, I.; Khan, M. Screening of free-living rhizospheric bacteria for their multiple plant growth promoting activities. Microbiol. Res. 2008, 163, 173-181. [CrossRef] [PubMed]

21. Dutta, S.; Surovy, M.Z.; Gupta, D.R.; Mahmud, N.U.; Chanclud, E.; Win, J.; Kamoun, S.; Islam, T. Genomic analyses reveal that biocontrol of wheat blast by Bacillus spp. may be linked with production of antimicrobial compounds and induced systemic resistance in host plants. Figshare 2018, 1-7.

22. Guo, Q.; Li, Y.; Lou, Y.; Shi, M.; Jiang, Y.; Zhou, J.; Sun, Y.; Xue, Q.; Lai, H. Bacillus amyloliquefaciens Ba13 induces plant systemic resistance and improves rhizosphere micro ecology against tomato yellow leaf curl virus disease. Appl. Soil Ecol. 2019, 137, 154-166. [CrossRef]

23. Haney, C.H.; Wiesmann, C.L.; Shapiro, L.R.; Melnyk, R.A.; O'Sullivan, L.R.; Khorasani, S.; Xiao, L.; Han, J.; Bush, J.; Carrillo, J. Rhizosphere-associated Pseudomonas induce systemic resistance to herbivores at the cost of susceptibility to bacterial pathogens. Mol. Ecol. 2018, 27, 1833-1847. [CrossRef] [PubMed]

24. Takishita, Y.; Charron, J.-B.; Smith, D.L. Biocontrol rhizobacterium Pseudomonas sp. 23S induces systemic resistance in tomato (Solanum lycopersicum L.) against bacterial canker Clavibacter michiganensis subsp. michiganensis. Front. Microbiol. 2018, 9, 2119. [CrossRef] [PubMed]

25. Duy, M.; Hoi, N.; Ve, N.; Thuc, L.; Trang, N. Influence of cellulomonas Flavigena, Azospirillum sp. and Psudomonas sp. on rice growth and yield grown in submerged soil amended in rice straw. Recent Trends PGPR Res. Sust. Crop Product. 2016, 238-242.

26. Hossain, M.; Ran, C.; Liu, K.; Ryu, C.-M.; Rasmussen-Ivey, C.; Williams, M.; Hassan, M.; Choi, S.-K.; Jeong, H.; Newman, M.; et al. Deciphering the conserved genetic loci implicated in plant disease control through comparative genomics of Bacillus amyloliquefaciens subsp. plantarum. Front. Plant Sci. 2015, 6, 631. [CrossRef]

27. Disi, J.O.; Mohammad,H.K.; Lawrence, K.; Kloepper, J.; Fadamiro, H. A soil bacterium can shape belowground interactions between maize, herbivores and entomopathogenic nematodes. Plant Soil 2019, 437, 83-92. [CrossRef]

28. Hassan, M.K.; McInroy, J.A.; Jones, J.; Shantharaj, D.; Liles, M.R.; Kloepper, J.W. Pectin-Rich Amendment Enhances Soybean Growth Promotion and Nodulation Mediated by Bacillus Velezensis Strains. Plants 2019, 8, 120. [CrossRef]

29. Wang, E.; Martinez-Romero, E. Sesbania herbacea-Rhizobium huautlense nodulation in flooded soils and comparative characterization of S. herbacea-nodulating Rhizobia in different environments. Microb. Ecol. 2000, 40, 25-32. [CrossRef]

30. Kumawat, K.; Sharma, P.; Sirari, A.; Singh, I.; Gill, B.; Singh, U.; Saharan, K. Synergism of Pseudomonas aeruginosa (LSE-2) nodule endophyte with Bradyrhizobium sp.(LSBR-3) for improving plant growth, nutrient acquisition and soil health in soybean. World J. Microbiol. Biotechnol. 2019, 35, 47. [CrossRef] [PubMed]

31. Harman, G.E.; Uphoff, N. Symbiotic Root-Endophytic Soil Microbes Improve Crop Productivity and Provide Environmental Benefits. Scientifica 2019, 2019, 1-25. [CrossRef]

32. Chauhan, H.; Bagyaraj, D.; Selvakumar, G.; Sundaram, S. Novel plant growth promoting rhizobacteriaProspects and potential. Appl. Soil Ecol. 2015, 95, 38-53. [CrossRef]

33. Manjunath, M.; Prasanna, R.; Sharma, P.; Nain, L.; Singh, R. Developing PGPR consortia using novel genera Providencia and Alcaligenes along with cyanobacteria for wheat. Arch. Agron. Soil Sci. 2011, 57, 873-887. [CrossRef] 
34. Franco-Correa, M.; Quintana, A.; Duque, C.; Suarez, C.; Rodríguez, M.X.; Barea, J.-M. Evaluation of actinomycete strains for key traits related with plant growth promotion and mycorrhiza helping activities. Appl. Soil Ecol. 2010, 45, 209-217. [CrossRef]

35. Lee, J.Y.; Hwang, B.K. Diversity of antifungal actinomycetes in various vegetative soils of Korea. Can. J. Microbiol. 2002, 48, 407-417. [CrossRef] [PubMed]

36. Parke, J.L. Root colonization by indigenous and introduced microorganisms. In The Rhizosphere and Plant Growth: Papers Presented at a Symposium Held May 8-11, 1989, at the Beltsville Agricultural Research Center (BARC), Beltsville, Maryland; Keister, D.L., Cregan, P.B., Eds.; Springer: Dordrecht, The Netherlands, 1991; pp. 33-42. [CrossRef]

37. Benizri, E.; Baudoin, E.; Guckert, A. Root colonization by inoculated plant growth-promoting rhizobacteria. Biocontrol Sci. Technol. 2001, 11, 557-574. [CrossRef]

38. Newman, E.; Watson, A. Microbial abundance in the rhizosphere: A computer model. Plant Soil 1977, 48, 17-56. [CrossRef]

39. Howie, W.; Cook, R.; Weller, D. Effects of soil matric potential and cell motility on wheat root colonization by fluorescent pseudomonads suppressive to take-all. Phytopathology 1987, 77, 286-292. [CrossRef]

40. Dekkers, L.C.; Van Der Bij, A.J.; Mulders, I.H.; Phoelich, C.C.; Wentwoord, R.A.; Glandorf, D.C.; Wijffelman, C.A.; Lugtenberg, B.J. Role of the O-antigen of lipopolysaccharide, and possible roles of growth rate and of NADH: Ubiquinone oxidoreductase (nuo) in competitive tomato root-tip colonization by Pseudomonas fluorescens WCS365. Mol. Plant-Microbe Interact. 1998, 11, 763-771. [CrossRef] [PubMed]

41. De Weger, L.A.; Bakker, P.A.; Schippers, B.; Van Loosdrecht, M.C.; Lugtenberg, B.J. Pseudomonas spp. with mutational changes in the $\mathrm{O}$-antigenic side chain of their lipopolysaccharide are affected in their ability to colonize potato roots. Sign. Mol. Plants Plant-Microbe Interact. 1989, 36, 197-202.

42. Simons, M.; Van Der Bij, A.J.; Brand, I.; De Weger, L.A.; Wijffelman, C.A.; Lugtenberg, B. Gnotobiotic system for studying rhizosphere colonization by plant growth-promoting Pseudomonas bacteria. Mol. Plant-Microbe Interact. MPMI 1996, 9, 600-607. [CrossRef] [PubMed]

43. Steenhoudt, O.; Vanderleyden, J. Azospirillum, a free-living nitrogen-fixing bacterium closely associated with grasses: Genetic, biochemical and ecological aspects. FEMS Microbiol. Rev. 2000, 24, 487-506. [CrossRef] [PubMed]

44. Dekkers, L.C.; Phoelich, C.C.; Van Der Fits, L.; Lugtenberg, B.J. A site-specific recombinase is required for competitive root colonization by Pseudomonas fluorescens WCS365. Proc. Natl. Acad. Sci. USA 1998, 95, 7051-7056. [CrossRef]

45. Dekkers, L.C.; Mulders, I.H.; Phoelich, C.C.; Chin-A-Woeng, T.F.; Wijfjes, A.H.; Lugtenberg, B.J. The sss colonization gene of the tomato-Fusarium oxysporum f. $\mathrm{sp}$. radicis-lycopersici biocontrol strain Pseudomonas fluorescens WCS365 can improve root colonization of other wild-type Pseudomonas spp. bacteria. Mol. Plant-Microbe Interact. 2000, 13, 1177-1183. [CrossRef]

46. Xu, Z.; Zhang, H.; Sun, X.; Liu, Y.; Yan, W.; Xun, W.; Shen, Q.; Zhang, R. Bacillus velezensis Wall Teichoic Acids Are Required for Biofilm Formation and Root Colonization. Appl. Environ. Microbiol. 2019, 85, e02116-e02118. [CrossRef]

47. Glick, B.R. The enhancement of plant growth by free-living bacteria. Can. J. Microbiol. 1995, 41, $109-117$. [CrossRef]

48. Vessey, J.K. Plant growth promoting rhizobacteria as biofertilizers. Plant Soil 2003, 255, 571-586. [CrossRef]

49. Prasad, M.; Srinivasan, R.; Chaudhary, M.; Choudhary, M.; Jat, L.K. Plant Growth Promoting Rhizobacteria (PGPR) for Sustainable Agriculture: Perspectives and Challenges. In PGPR Amelioration in Sustainable Agriculture; Woodhead Publishing: Sawston, UK, 2019; pp. 129-157.

50. Bhat, M.A. Plant Growth Promoting Rhizobacteria (PGPR) for Sustainable and Eco-Friendly Agriculture. Acta Sci. Agric. 2019, 3, 23-25.

51. Hassan, M. The Role of Pectin Utilization in Root Colonization and Plant Growth-Promotion by Bacillus amyloliquefaciens subsp. Plantarum (Bap). Master's Thesis, Auburn University, Auburn, ME, USA, 2016.

52. Lakshmanan, V.; Castaneda, R.; Rudrappa, T.; Bais, H.P. Root transcriptome analysis of Arabidopsis thaliana exposed to beneficial Bacillus subtilis FB17 rhizobacteria revealed genes for bacterial recruitment and plant defense independent of malate efflux. Planta 2013, 238, 657-668. [CrossRef] [PubMed]

53. Van Overbeek, L.; Van Elsas, J. Root exudate-induced promoter activity in Pseudomonas fluorescens mutants in the wheat rhizosphere. Appl. Environ. Microbiol. 1995, 61, 890-898. [PubMed] 
54. Zhalnina, K.; Louie, K.B.; Hao, Z.; Mansoori, N.; Da Rocha, U.N.; Shi, S.; Cho, H.; Karaoz, U.; Loqué, D.; Bowen, B.P. Dynamic root exudate chemistry and microbial substrate preferences drive patterns in rhizosphere microbial community assembly. Nat. Microbiol. 2018, 3, 470. [CrossRef] [PubMed]

55. Bolton, H.F.; Elliott, L.F. Microbial ecology of the rhizosphere. In Soil Microbial Ecology; Marcel Dekker: New York, NY, USA, 1993; pp. 27-63.

56. Bais, H.P.; Park, S.-W.; Weir, T.L.; Callaway, R.M.; Vivanco, J.M. How plants communicate using the underground information superhighway. Trends Plant Sci. 2004, 9, 26-32. [CrossRef] [PubMed]

57. Bertin, C.; Yang, X.; Weston, L.A. The role of root exudates and allelochemicals in the rhizosphere. Plant Soil 2003, 256, 67-83. [CrossRef]

58. Tsuno, Y.; Fujimatsu, T.; Endo, K.; Sugiyama, A.; Yazaki, K. Soyasaponins, a new class of root exudates in soybean (Glycine max). Plant Cell Physiol. 2017, 59, 366-375. [CrossRef] [PubMed]

59. Liu, Y.; Guan, D.; Jiang, X.; Ma, M.; Li, L.; Cao, F.; Chen, H.; Shen, D.; Li, J. Proteins involved in nodulation competitiveness of two Bradyrhizobium diazoefficiens strains induced by soybean root exudates. Biol. FERTIL. Soils 2015, 51, 251-260. [CrossRef]

60. Walker, T.S.; Bais, H.P.; Grotewold, E.; Vivanco, J.M. Root exudation and rhizosphere biology. Plant Physiol. 2003, 132, 44-51. [CrossRef] [PubMed]

61. Bengough, A.; McKenzie, B. Sloughing of root cap cells decreases the frictional resistance to maize (Zea mays L.) root growth. J. Exp. Bot. 1997, 48, 885-893. [CrossRef]

62. Hawes, M.C.; Gunawardena, U.; Miyasaka, S.; Zhao, X. The role of root border cells in plant defense. Trends Plant Sci. 2000, 5, 128-133. [CrossRef]

63. Nguyen, C. Rhizodeposition of organic C by plants: Mechanisms and controls. Agronomie 2003, 23, 375-396. [CrossRef]

64. Kuzyakov, Y.; Xu, X. Competition between roots and microorganisms for nitrogen: Mechanisms and ecological relevance. New Phytol. 2013, 198, 656-669. [CrossRef] [PubMed]

65. Cannesan, M.A.; Durand, C.; Burel, C.; Gangneux, C.; Lerouge, P.; Ishii, T.; Laval, K.; Follet-Gueye, M.-L.; Driouich, A.; Vicré-Gibouin, M. Effect of arabinogalactan proteins from the root caps of pea and Brassica napus on Aphanomyces euteiches zoospore chemotaxis and germination. Plant Physiol. 2012, 159, 1658-1670. [CrossRef] [PubMed]

66. Wen, F.; VanEtten, H.D.; Tsaprailis, G.; Hawes, M.C. Extracellular proteins in pea root tip and border cell exudates. Plant Physiol. 2007, 143, 773-783. [CrossRef] [PubMed]

67. Whipps, J.; Lynch, J. Energy losses by the plant in rhizodeposition. Ann. Proc. Phytochem. Soc. 1985, 26, $59-71$.

68. Six, J.; Bossuyt, H.; Degryze, S.; Denef, K. A history of research on the link between (micro) aggregates, soil biota, and soil organic matter dynamics. Soil Tillage Res. 2004, 79, 7-31. [CrossRef]

69. Curl, E.T.B. The rhizosphere. Science 1986, 203, 1253-1255.

70. Wang, Z.; Lü, J.; Li, F.; Xu, B. Rhizodeposition and its role in carbon cycling in plant-soil system. J. Appl. Ecol. 2006, 17, 1963-1968.

71. Bowsher, A.W.; Evans, S.; Tiemann, L.K.; Friesen, M.L. Effects of soil nitrogen availability on rhizodeposition in plants: A review. Plant Soil 2018, 423, 59-85. [CrossRef]

72. Jones, D.L.; Hodge, A.; Kuzyakov, Y. Plant and mycorrhizal regulation of rhizodeposition. New Phytol. 2004, 163, 459-480. [CrossRef]

73. Sievers, A.; Braun, M.; Monshausen, G.B. The root cap: Structure and function. In Plant Roots: The hidden Half; CRC Press: Boca Raton, FL, USA, 2002; Volume 3, pp. 33-47.

74. Dennis, P.G.; Miller, A.J.; Hirsch, P.R. Are root exudates more important than other sources of rhizodeposits in structuring rhizosphere bacterial communities? FEMS Microbiol. Ecol. 2010, 72, 313-327. [CrossRef] [PubMed]

75. Yadav, B.K.; Akhtar, M.S.; Panwar, J. Rhizospheric plant-microbe interactions: Key factors to soil fertility and plant nutrition. In Plant Microbes Symbiosis: Applied Facets; Springer: New Delhi, India, 2015; pp. 127-145.

76. Hütsch, B.W.; Augustin, J.; Merbach, W. Plant rhizodeposition-An important source for carbon turnover in Soils. J. Plant Nutr. Soil Sci. 2002, 165, 397-407. [CrossRef]

77. Kögel-Knabner, I. The macromolecular organic composition of plant and microbial residues as inputs to soil organic matter. Soil Biol. Biochem. 2002, 34, 139-162. [CrossRef] 
78. White, L.J.; Ge, X.; Brözel, V.S.; Subramanian, S. Root isoflavonoids and hairy root transformation influence key bacterial taxa in the soybean rhizosphere. Environ. Microbiol. 2017, 19, 1391-1406. [CrossRef] [PubMed]

79. Hawes, M.; Brigham, L.; Wen, F.; Woo, H.; Zhu, Y. Function of root border cells in plant health: Pioneers in the rhizosphere. Ann. Rev. Phytopathol. 1998, 36, 311-327. [CrossRef]

80. Hamamoto, L.; Hawes, M.C.; Rost, T.L. The production and release of living root cap border cells is a function of root apical meristem type in dicotyledonous angiosperm plants. Ann. Bot. 2006, 97, 917-923. [CrossRef]

81. Driouich, A.; Durand, C.; Cannesan, M.-A.; Percoco, G.; Vicré-Gibouin, M. Border cells versus border-like cells: Are they alike? J. Exp. Bot. 2010, 61, 3827-3831. [CrossRef]

82. Curlango-Rivera, G.; Pew, T.; VanEtten, H.D.; Zhongguo, X.; Yu, N.; Hawes, M.C. Measuring root disease suppression in response to a compost water extract. Phytopathology 2013, 103, 255-260. [CrossRef]

83. Endo, I.; Tange, T.; Osawa, H. A cell-type-specific defect in border cell formation in the Acacia mangium root cap developing an extraordinary sheath of sloughed-off cells. Ann. Bot. 2011, 108, 279-290. [CrossRef] [PubMed]

84. Stephenson, M.B.; Hawes, M.C. Correlation of pectin methylesterase activity in root caps of pea with root border cell separation. Plant Physiol. 1994, 106, 739-745. [CrossRef] [PubMed]

85. Wen, F.; Zhu, Y.; Hawes, M. Expression of a pectinmethylesterase-like gene in pea root tips influences extracellular pH, cell morphology and border cell separation. Plant Cell 1999, 11, 1129-1140. [CrossRef] [PubMed]

86. Durand, C.; Vicré-Gibouin, M.; Follet-Gueye, M.L.; Duponchel, L.; Moreau, M.; Lerouge, P.; Driouich, A. The Organization Pattern of Root Border-Like Cells of Arabidopsis Is Dependent on Cell Wall Homogalacturonan. Plant Physiol. 2009, 150, 1411-1421. [CrossRef] [PubMed]

87. Hawes, M.; Brigham, L. Impact of root border cells on microbial populations in the rhizosphere. Adv. Plant Pathol. 1992, 8, 119-148.

88. Hawes, M. Living plant cells released from the root cap: A regulator of microbial populations in the rhizosphere. In The Rhizosphere and Plant Growth; Springer: Dordrecht, The Netherlands, 1991; Volume 129, pp. 19-27.

89. Canellas, L.P.; Olivares, F.L. Production of border cells and colonization of maize root tips by Herbaspirillum seropedicae are modulated by humic acid. Plant Soil 2017, 417, 403-413. [CrossRef]

90. Driouich, A.; Follet-Gueye, M.-L.; Vicré-Gibouin, M.; Hawes, M. Root border cells and secretions as critical elements in plant host defense. Curr. Opin. Plant Biol. 2013, 16, 489-495. [CrossRef]

91. Kuzyakov, Y. Factors affecting rhizosphere priming effects. J. Plant Nutr. Soil Sci. 2002, 165, 382-396. [CrossRef]

92. Rovira, A. Plant root excretions in relation to the rhizosphere effect. Plant Soil 1956, 7, 178-194. [CrossRef]

93. Marschner, P.; Crowley, D.; Rengel, Z. Rhizosphere interactions between microorganisms and plants govern iron and phosphorus acquisition along the root axis-model and research methods. Soil Biol. Biochem. 2011, 43, 883-894. [CrossRef]

94. De-La-Peña, C.; Lei, Z.; Watson, B.S.; Sumner, L.W.; Vivanco, J.M. Root-microbe communication through protein secretion. J. Biol. Chem. 2008, 283, 25247-25255. [CrossRef] [PubMed]

95. Sasse, J.; Martinoia, E.; Northen, T. Feed Your Friends: Do Plant Exudates Shape the Root Microbiome? Trends Plant Sci. 2017, 23, P25-P41. [CrossRef] [PubMed]

96. Parmar, N.; Dufresne, J. Beneficial interactions of plant growth promoting rhizosphere microorganisms. In Bioaugmentation, Biostimulation and Biocontrol; Springer: Berlin/Heidelberg, Germany, 2011; pp. $27-42$.

97. Hirsch, A.M.; Bauer, W.D.; Bird, D.M.; Cullimore, J.; Tyler, B.; Yoder, J.I. Molecular signals and receptors: Controlling rhizosphere interactions between plants and other organisms. Ecology 2003, 84, 858-868. [CrossRef]

98. Jones, D.L.; Farrar, J.; Giller, K.E. Associative nitrogen fixation and root exudation-What is theoretically possible in the rhizosphere? Symbiosis 2003, 35, 19-38.

99. Zheng, X.; Sinclair, J. Chemotactic response of Bacillus megaterium strain B153-2-2 to soybean root and seed exudates. Physiol. Mol. Plant Pathol. 1996, 48, 21-35. [CrossRef]

100. Reichling, J. Plant-microbe interactions and secondary metabolites with antibacterial, antifungal and antiviral properties. Annu. Plant Rev. Online 2018, 324, 214-347.

101. Mohanram, S.; Kumar, P. Rhizosphere microbiome: Revisiting the synergy of plant-microbe interactions. Ann. Microbiol. 2019, 69, 307-320. [CrossRef] 
102. Bacilio-Jiménez, M.; Aguilar-Flores, S.; Ventura-Zapata, E.; Pérez-Campos, E.; Bouquelet, S.; Zenteno, E. Chemical characterization of root exudates from rice (Oryza sativa) and their effects on the chemotactic response of endophytic bacteria. Plant Soil 2003, 249, 271-277. [CrossRef]

103. Walker, T.S.; Bais, H.P.; Halligan, K.M.; Stermitz, F.R.; Vivanco, J.M. Metabolic profiling of root exudates of Arabidopsis thaliana. J. Agric. Food Chem. 2003, 51, 2548-2554. [CrossRef]

104. Dutta, S.; Podile, A.R. Plant growth promoting rhizobacteria (PGPR): The bugs to debug the root zone. Crit. Rev. Microbiol. 2010, 36, 232-244. [CrossRef]

105. Prashar, P.; Kapoor, N.; Sachdeva, S. Rhizosphere: Its structure, bacterial diversity and significance. Rev. Environ. Sci. Bio/Technol. 2014, 13, 63-77. [CrossRef]

106. Liu, H.; Carvalhais, L.C.; Crawford, M.; Singh, E.; Dennis, P.G.; Pieterse, C.M.J.; Schenk, P.M. Inner Plant Values: Diversity, Colonization and Benefits from Endophytic Bacteria. Front. Microbiol. 2017, 8, 2552. [CrossRef] [PubMed]

(C) 2019 by the authors. Licensee MDPI, Basel, Switzerland. This article is an open access article distributed under the terms and conditions of the Creative Commons Attribution (CC BY) license (http://creativecommons.org/licenses/by/4.0/). 